\title{
Observations on Granite Weathering Phenomena, Mount Keinath, Northern Victoria Land, Antarctica
}

\author{
H. M. French ${ }^{1 *}$ and M. Guglielmin ${ }^{2}$ \\ ${ }^{1}$ Departments of Geography and Earth Sciences and Ottawa-Carleton Geoscience Centre, University of Ottawa, \\ Ottawa, Canada \\ 2 Programma Nazionale di Ricerche in Antartide (PNRA), Milan, Italy
}

\begin{abstract}
Rock varnish, erosional grooves, and well-developed cavernous weathering phenomena occur in close association on a small biotite-monzogranite nunatak in the Northern Foothills region, Northern Victoria Land, Antarctica. The grooves, similar in appearance to the 'rinnenkarren' described in the karst literature, are developed on steeply inclined $\left(>35^{\circ}\right)$ bedrock surfaces while the rock varnish occurs on adjacent, more gently sloping $\left(<15^{\circ}\right)$ bedrock surfaces. The varnish forms a resistant carapace through which small weathering pits have developed and below which are large cavernously weathered hollows (taffoni). We argue that the intimate association between the grooves and the rock varnish indicate the nunatak has been exposed to a long period of subaerial weathering. The preservation of both phenomena supports (a) the idea that landscape modification in this exceptionally cold and arid region of Antarctica is very slow and (b) the long-term stability of the Antarctic ice sheet. Copyright (C) 2002 John Wiley \& Sons, Ltd.
\end{abstract}

KEY WORDS: granite; cryogenic weathering; grooves; rock varnish; Antarctica

\section{INTRODUCTION}

We have recently described unusual grooves, or rock 'furrows' (French and Guglielmin, 2002), from the summit of Mount Keinath $\left(74^{\circ} 34^{\prime} \mathrm{S} ; 163^{\circ}\right.$ $57^{\prime} \mathrm{E}$ ), a small nunatak located approximately $30 \mathrm{~km}$ inland from the Italian PNRA Terra Nova Bay research station in Northern Victoria Land, Antarctica (Figure 1). Previously, aspects of the geomorphology and geocryology of the ice-free areas surrounding the PNRA station have been described (French and Guglielmin, 1999, 2000a, 2000b) and earlier literature is referenced in these papers. The present report documents additional weathering phenomena that we observed on the Mount Keinath summit and

* Correspondence to: Prof. H. M. French, Departments of Geography and Earth Sciences, University of Ottawa, Ottawa, Ontario KIN 6N5, Canada. E-mail: hughfrench@rogers.com discusses their implications for periglacial landscape evolution and the long-term stability of the Antarctic ice-sheet.

The nunatak rises approximately $250 \mathrm{~m}$ above the level of the current trim-line and reaches a maximum height of $1090 \mathrm{~m}$ a.s.l. The bedrock is a biotite-monzogranite of Ordovician-Devonian age, mapped as part of the Granite Harbour Intrusives (Carmignani et al., undated; Baroni 1996). Visits to the summit were made on several occasions during November 1998.

\section{CLIMATIC CONDITIONS}

PNRA climatic records from the Tourmalene Plateau automatic weather station (AWS 7536; Baroni, 1996), located on the Priestley Glacier at an elevation of $1700 \mathrm{~m}$ a.s.1., are probably the most representative Received 2 August 2001 Revised 10 February 2002 


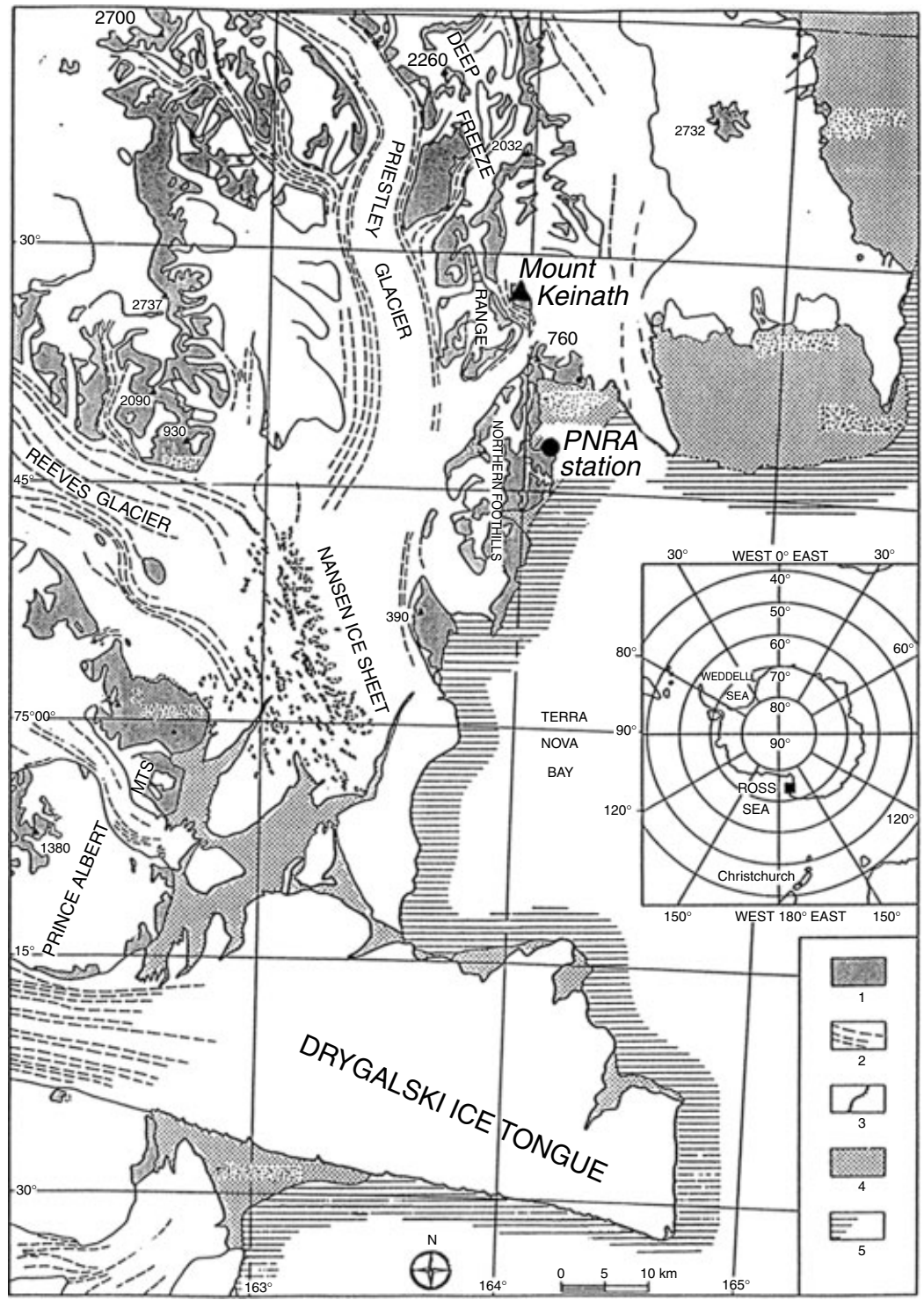

Figure 1 Map of the Northern Foothills region, Northern Victoria Land, showing location of Mount Keinath. Ice-free areas are stippled.

of the conditions experienced on the Mount Keinath summit. Station AWS 7536 indicates average air temperatures of -25 to $-30^{\circ} \mathrm{C}$ for the seven month period from March to October. These rise to maxima of only -10 to $-15^{\circ} \mathrm{C}$ in December and early January. Therefore, given the lower elevation of Mount Keinath, we should assume that the probable maximum air temperature in summer on the summit rarely exceeds $-5^{\circ} \mathrm{C}$ and the probable mean annual air temperature (MAAT) is somewhere between -10 and $-20^{\circ} \mathrm{C}$.
An automatic weather station, installed on the summit subsequent to our initial field investigations, indicates maximum air temperatures of less than $2{ }^{\circ} \mathrm{C}$ in summer. However, rock surface temperatures may be considerably higher due to both direct and indirect (i.e. snow albedo) solar radiation, as stressed in general terms by Hall and André (2001). Occasional surface temperatures in excess of $20^{\circ} \mathrm{C}$ might reasonably be expected on sunny spring days, even when air temperatures are well below zero. We have no data concerning precipitation but, in common 
with most other nunataks in Eastern Antarctica, this occurs almost entirely in the form of snow. It is probably less than $100 \mathrm{~mm}$ per annum. In keeping with its elevation, the summit probably avoids the strong and persistent katabatic winds that flow from the interior plateau along the large valley glaciers. Nevertheless, winds are still strong.

\section{WEATHERING PHENOMENA}

Interesting combinations of geomorphological phenomena on the Mount Keinath summit illustrate some of the peculiarities of granite weathering in this exceptionally cold and arid environment.

First, the grooves are micro-scale phenomena (Figure 2), remarkably similar in form to the rinnenkarren mentioned in the karst literature. They run down the steeper $\left(>35^{\circ}\right)$ rock surfaces and disappear beneath the perennial ice covers that surround the nunatak. For the most part, the grooves are straight, and typically $10-30 \mathrm{~cm}$ deep and $20-80 \mathrm{~cm}$ wide. Morphometric and other details are given in French and Guglielmin (2002).

A second characteristic of the exposed bedrock on the summit is the occurrence of a distinctive, reddishbrown (5YR 5/8) rock varnish. This is present, not within the grooves but on the adjacent, more gently inclined $\left(<15^{\circ}\right)$ bedrock surfaces (Figure 3 ). These surfaces are often broken, or 'pitted', by small circular or near-circular hollows. Almost certainly, these are granite weathering pits that have been either accentuated or delineated by the relatively more resistant rock-varnish surface. For example, at

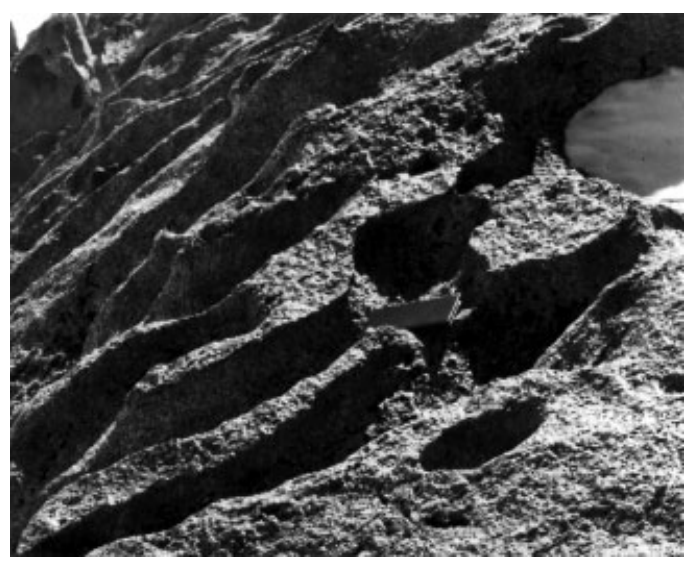

Figure 2 Grooves, similar to rillenkarren, occur on the steep $\left(>35^{\circ}\right)$ bedrock surfaces of the Mount Keinath summit (photo: H. M. French)

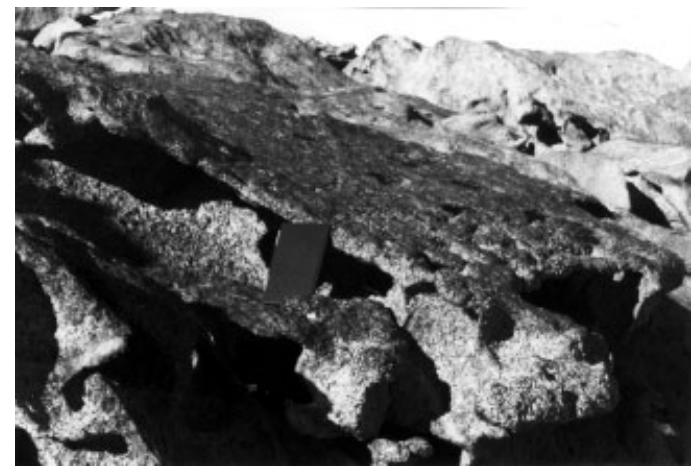

Figure 3 A rock-varnish veneer forms a protective carapace to low angled $\left(>15^{\circ}\right)$ bedrock surfaces of the Mount Keinath summit. Note the cavernous weathering (taffoni) that is actively developing. Notebook is $15 \mathrm{~cm}$ long (photo: H. M. French).

the locality illustrated in Figure 3, the rock varnish forms the exterior, case-hardened, surface of a $10 \mathrm{~cm}$ thick carapace that has developed over an exfoliated granite slab, $\sim 1.0 \mathrm{~m}$ thick, that has been completely consumed by cavernous weathering from beneath. The case-hardened surface however, is pitted with 'windows' or holes, indicating that, as the cavernous weathering progressively enlarges beneath the hollow beneath the rock-varnish carapace, it 'captures' the hollows or pits that had previously developed on the surface.

It was not possible to identify any simple field relations existing between the grooves and the rock varnish, except to observe that the steep bedrock outcrops where the grooves were developed did not display rock varnish. On the other hand, the taffoni phenomena are among the best that we have observed in the Northern Foothills region. It seems probable that they have been enhanced and/or preserved by the protective case-hardening provided by the rock varnish. The morphological and spatial relationships between the various phenomena, as inferred from our field observations, are summarized in Figure 4.

\section{THE WEATHERING PROCESSES}

Our comments here are speculative and require further field investigation.

Because of the sub-zero MAAT experienced on the summit of Mount Keinath, traditional freeze-thaw can be largely discounted as the primary weathering process for the grooves, pits and cavernous hollows described. Instead, attention must focus upon thermal conditions rather than moisture conditions. For example, the dark monzogranite bedrock probably 


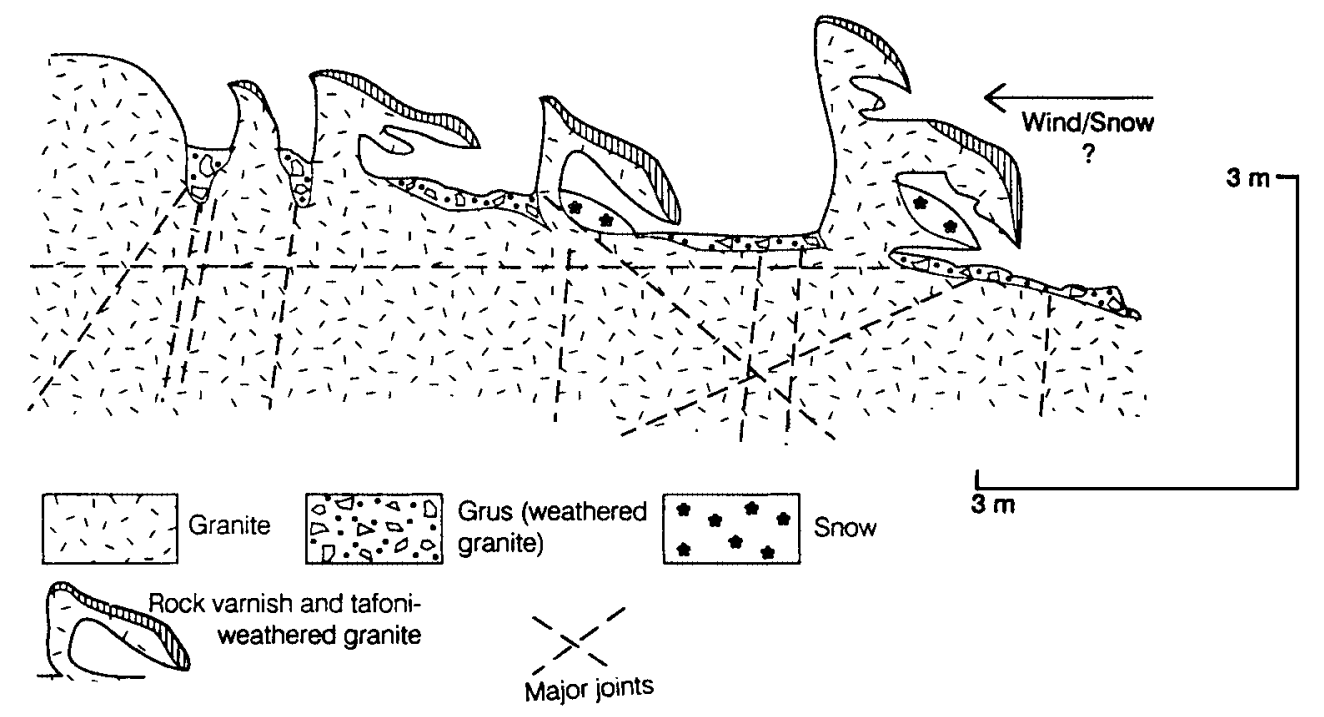

Figure 4 Schematic diagram illustrates the relationship between granite bedrock, grooves, cavernous weathering and rock varnish on Mount Keinath.

experiences exceptionally high surface temperatures, especially in the spring when air temperatures remain far below zero. This is because of the high quantities of both direct and reflected solar radiation that would be received at that time of year. Reflected solar radiation from the surrounding perennial snow and ice covers would be especially important. We have suggested elsewhere (French and Guglielmin, 2002) that these high rock-surface temperatures could result in the repeated thawing and refreezing of any snow or ice particles that might be present and that this might be the mechanism of erosion of the grooves. Equally, we have suggested (French and Guglielmin, 2000b) that granitic rocks experience mechanical weathering under cryogenic conditions through the preferential disintegration of the quartz minerals. This is probably due to the freezing of saline gas-liquid inclusions at sub-zero temperatures in micro-cracks on the surface of the quartz particles (see Konischchev, 1982; Konischchev and Rogov, 1993). However, the increasing brittleness of quartz at low temperatures may also be important, as might be thermal shock and/or thermal stress fatigue acting upon the different minerals within the rock. In summary, we suggest that erosion of the grooves occurs by mechanical weathering, whereby shortlived episodes of meltwater activity that result from high (i.e. above-zero) surface temperatures remove rock fragments that have been produced by the preferential disintegration of quartz grains at sub-zero ground temperatures.
The role played by the rock varnish is to act as casehardening, thereby enhancing the development and preservation of cavernous (taffoni) weathering. It is significant that the varnish occurs only on the lowerangled rock surfaces which, presumably, receive less heating than steeper slopes. Moreover, the potential energy of running water to effect groove erosion is much less than on the steeper slopes.

Thin sections provide support for both the weathering processes that are being proposed and the nature of the protective rock varnish. For example, two sections, viewed under cross-polarized light, are illustrated in Figure 5. In common with other granitic rocks examined from the immediate vicinity of the PNRA Terra Nova station (e.g. see French and Guglielmin, 2000b, Figures 3 and 4), the quartz minerals display large open fractures while the feldspars appear relatively undisturbed (Figure 5A). The apparent susceptibility of the quartz particles to disintegration, as compared with the feldspars, is unusual but unequivocal.

The rock varnish consists of cumulative layers of reddish-brown material, as much as $0.05 \mathrm{~mm}$ thick in places (Figure 5B). It is interpreted as the result of the oxidation of ferrous minerals, especially those contained within the biotite of the Mount Keinath monzogranite. It is traditionally assumed that iron oxides coat the feldspar grains and any other relatively unweathered minerals at the rock surface to give the characteristic reddish-brown stain (e.g. see Glasby et al., 1981; Campbell and Claridge, 

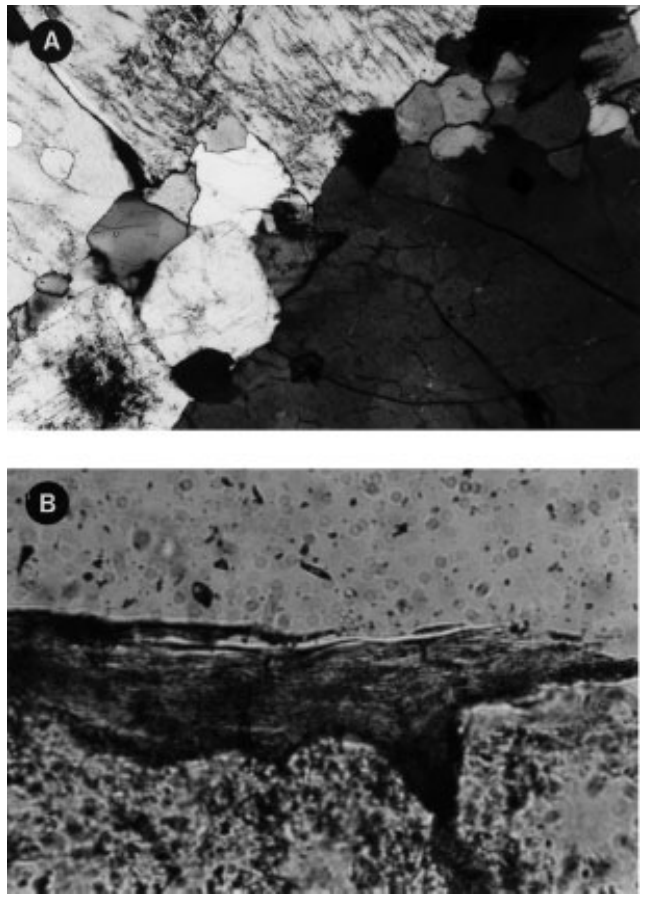

Figure 5 Thin sections of Mount Keinath monzogranite viewed under cross-polarized light. (A) Sample from within a cavernous hollow. The picture shows fractures within the quartz crystal (right) and relatively few fractures in the turbid plagioclase and microcline (left). There is no indication that fracturing has occurred along grain boundaries, as might be expected if thermal stress was the cause of the granular disintegration of the rock. Picture width is $2.2 \mathrm{~mm}$. (B) This section cuts through the rock varnish veneer on an exposed bedrock surface. Note the cumulative layering of the rock varnish, probably consisting of iron oxides. The underlying mineral in the picture is a feldspar. Picture width is $0.2 \mathrm{~mm}$.

1987, 124-129). Some investigators (e.g. Dorn et al., 1992; Dorn and Oberlander, 1982) argue that a biogeochemical origin should also be considered but, in the case of Mount Keinath, we prefer to stress the link between the iron oxide and the biotite. Whatever its precise origin, the rock varnish results in the rock exterior becoming sufficiently cemented to prevent the intergranular movement of salt solutions. Thus, the rock varnish, once formed, acts to enhance and preserve any cavernous weathered that might develop beneath the rock.

\section{DISCUSSION}

Our discussion focuses upon the significance of our observations as regards landscape evolution in this extremely cold and arid environment and the nature of Quaternary glaciation.
The hypothesis that the grooves are meltwater erosional micro-forms was first proposed by Bardin (1962, 1964). Later, Richer (1985) proposed a subglacial origin. Because of the absence of striations or other evidence of subglacial erosion, the latter explanation is discounted. Instead, we argue that mechanical weathering on the steeply inclined bedrock surfaces, resulting from either thermal shock or saline-induced cryogenic freeze-thaw oscillations, or both, would initially loosen grus-sized particles. These would then be removed by snowmelt. Once initiated, the grooves would act to further localize mechanical abrasion by inducing small wind vortices carrying snow crystals at extremely low temperatures. It seems fair to infer that the erosion of granite by these means must be an exceedingly slow process.

Rock varnish is also regarded as an extremely slow weathering process. Referring specifically to Antarctica, Campbell and Claridge (1987, 127-129) state that the 'surfaces on which pitted and stained rocks are found are always old, of the order of a million years or more'. In all probability, therefore, the longevity of exposure of the Mount Keinath summit would explain not only the rock varnish but also why the erosional grooves have been able to develop.

The time when glaciation commenced in Antarctica is unclear but it is now assumed to be during the mid-Miocene (Bartek et al., 1996; Denton et al., 1993). In Northern Victoria Land, Armienti and Baroni (1999) conclude that there was a change from warm-based to cold-based glaciers approximately 7.5-8.2 Ma. Since then, we can assume that the summit of Mount Keinath has been largely 'fossilized', remaining in a deeply frozen, permafrost state. Apart from the slow formation of the micro-erosional grooves and the continued surface hardening via slow rock-varnish accretion, the only active process is the cavernous weathering occurring beneath the rock varnish. In fact, we must assume very little landscape modification for several millions of years. Any other interpretation, involving either burial beneath a moving, warm-based continental ice cover, or subaerial exposure to intense freeze-thaw and the significant action of other periglacial weathering and erosional processes, would have led to the erosion, modification or destruction of both the grooves and the rock varnish.

\section{CONCLUSIONS}

Although we are unsure as to the correct geomorphological significance of the grooves, we believe their 
occurrence in close association with rock varnish supports the concept of a very slow rate of landscape evolution in this cold and arid environment. We suggest that our observations support other studies from Southern Victoria Land (e.g. Sugden et al., 1995; Summerfield et al., 1999) that stress the long term stability of the Antarctic ice sheet, and we imply that this concept should now be extended to the high, ice-free summits of Northern Victoria Land.

\section{ACKNOWLEDGEMENTS}

Research was conducted under the auspices of the Italian Antarctic Research Program (PNRA) (Project 2 a. 13, Professor F. Dramis, University of Rome 3) during the first period of the 1998-99 expedition. Logistics were supplied by the PNRA station at Terra Nova Bay. Assistance in thin-section analysis and mineral identification was provided by Dr A. E. Lalonde (Department of Earth Sciences, University of Ottawa). Leave by HMF from the University of Ottawa to participate in the 1998-99 PNRA expedition is gratefully acknowledged. Comments by three anonymous reviewers upon an earlier version of this paper, and by Kevin Hall upon a revised version, are much appreciated.

\section{REFERENCES}

Armienti P, Baroni C. 1999. Cenozoic climatic changes in Antarctica recorded by volcanic activity and landscape evolution. Geology 27: 617-620.

Bardin V. 1962. Borozoly na skalakh (rock furrows). Sovet Antarkticheskayaia Eksped. Inform. Bull. 35: 63-64. Translation in: Soviet Antarctic Expedition. 1964. Information Bulletin 4(3): 167.

Bardin V. 1964. O'rel'efoobrazuinschechei deialel'nosti talykh vod v gorokh Zernii korolevy Mod (relief-forming action of meltwater in the mountains of Queen Maud Land). Moscow Univ. Vestnik Ser 5 Geogr. 3: 90-91.

Baroni C. 1996. Mount Melbourne Quadrangle (Victoria Land). Antarctic Geomorphological and Glaciological 1:125,000 Map Series. Programma Nazionale di Richerche in Antartide (PNRA). Museo Nazionale dell'Antartide, Sezione di Scienze della Terra-Siena, Italy.

Bartek LR, Henry SA, Anderson JB, Barrett PJ. 1996. Seismic stratigraphy of McMurdo sound, Antarctica: implications for glacially-influenced early Cenozoic eustatic changes? Marine Geology 130: 79-98.

Campbell IB, Claridge GGC. 1987. Antarctica: Soils, Weathering Processes and Environment. Elsevier: Amsterdam.
Carmignani L, Ghezzo C, Gosso G, Lombardo B, Meccheri M, Montrasio A, Petrusati PC, Slavini F. Undated. Geological Map of the Area between David and Mariner Glaciers, Victoria Land, Antarctica. Scale 1:5,000,000. Programma Nazionale di Richerche in Antartide (PNRA), Firenza, Italy.

Denton GH, Sugden DE, Marchant DR, Hall BL, Welch TL. 1993. East Antarctic ice sheet sensitivity to Pliocene climatic change from a Dry Valleys perspective. Geografiska Annaler 74A: 155-204.

Dorn R, Oberlander TM. 1982. Rock varnish. Progress in Physical Geography 6: 317-367.

Dorn RI, Krinsley DH, Lin T, Anderson S, Clark J, Cahill TA, Gill TE. 1992. Manganese-rich rock varnish does occur in Antarctica. Chemical Geology 99: 289-298.

French HM, Guglielmin M. 1999. Observations on the icemarginal periglacial geomorphology of Terra Nova Bay, Northern Victoria Land, Antarctica. Permafrost and Periglacial Processes 10: 331-348.

French HM, Guglielmin M. 2000a. Frozen ground phenomena in the vicinity of Terra Nova Bay, Northern Victoria Land, Antarctica: A preliminary report. Geografiska Annaler 82A: 513-526.

French HM, Guglielmin M. 2000b. The cryogenic weathering of granite, northern Victoria Land, Antarctica. Permafrost and Periglacial Processes 11: 305-314.

French HM, Guglielmin M. 2002. Cryogenic grooves on a granite nunatak. Northern Victoria Land, Antarctica. Norsk Geografisk Tidsskrift 56: 112-116.

Glasby GP, McPherson JG, Kohn BP, Johnston JH, Kemp JR, Freeman AG, Tricker MJ. 1981. Desert varnish in southern Victoria Land, Antarctica. New Zealand Journal of Geology and Geophysics 24: 389-397.

Hall KJ, André M-F. 2001. New insights into rock weathering from high-frequency rock temperature data: an Antarctic study of weathering by thermal stress. Geomorphology 41: 23-35.

Konischchev VN. 1982. Characteristics of cryogenic weathering in the permafrost zone of the European USSR. Arctic and Alpine Research 14: 261-265.

Konischchev VN, Rogov VV. 1993. Investigations of cryogenic weathering in Europe and Northern Asia. Permafrost and Periglacial Processes 4: 49-64.

Richter W. 1985. Remarkable morphological forms in the Schirmacher Oasis, Dronning Maud Land, East Antarctica. Zeitschrift fur geologische Wissenschaften, 13(3): 389-398.

Sugden DE, Denton GH, Marchant DR. 1995. Landscape evolution of the Dry Valleys, Trans-Antarctic Mountains: tectonic implications. Journal of Geophysical Research 100(B7): 9947-9967.

Summerfield MA, Stuart FM, Cockbum HAP, Sugden DE, Denton GH, Dunai T, Marchant DR. 1999. Long-term rates of denudation in the Dry Valleys, Trans-Antarctic Mountains, Southern Victoria Land, Antarctica based on in-situ-produced cosmogenic $\mathrm{Ne}-21$. Geomorphology 27: $113-129$. 